\title{
Macro-Economic Variables and Stock Prices: Empirical Evidence From Sri Lanka
}

\author{
S. Anandasayanan \\ Senior Lecturer, Dept. of Financial Management \\ University of Jaffna, Sri Lanka \\ E-mail: sayananakshi@yahoo.com
}

Received: January 27, 2019 Accepted: October 24, 2019 Published: November 6, 2019

doi:10.5296/ijafr.v9i4.14280 URL: https://doi.org/10.5296/ijafr.v9i4.14280

\begin{abstract}
Economic strength in a country could be measured by macroeconomics variables. Inflation, interest rate, unemployment rate and GDP Deflator are some macroeconomics variables that show economic condition in Sri Lanka. The impact of macro-economic variables on share prices is uncontrollable. This study investigates the relationship between macroeconomic variables and stock prices in Sri Lankan stock market using yearly time series data for the period from 1990 to 2017. The Ordinary Least Square regression was carried out using four macroeconomic variables for stock prices. The results shows that the higher R Square value (72.4911) which justifies higher explanatory power of macroeconomic variables in explaining stock prices. Consistent with similar results of the developed as well as emerging market studies, interest rate and inflation rate and unemployment rate react mainly negatively to stock prices in the Colombo Stock Exchange. These findings hold practical implications for policy makers, stock market regulators, investors and stock market analysts.
\end{abstract}

Keywords: Colombo Stock Exchange, Macroeconomic variables, Stock prices

\section{Background of the Study}

Macroeconomic variables affect the performance of the stock market. Investors consider macroeconomic variables when they value stocks. Interest rates, inflation rate, GDP deflator and unemployment rate are very important among these macroeconomic variables which affect the performance of the stock market. This study is to identify the impact of macroeconomic variables on stock prices. It is believed that domestic economic fundamentals play determining role in the performance of stock market. Knowledge of stock market sensitivity to macroeconomic behavior of key variables and vice-versa is important in many 
areas of investments and finance. This study will be useful to understand this relationship between macroeconomic variables and stock prices.

\subsection{Research Problem}

A number of studies have been carried out to find out the relationship between the macroeconomic variable and stock prices in the past. The findings of these studies show that there was a strong relationship between macroeconomic variable and stock prices via inflation and interest rate. Some studies showed no relationship between the economies and the stock markets of less developed countries, like Asian markets. However, according to Bhunia (2012), there exists a negative association among inflation and stock prices. However, the paucity of literature on the effects of macroeconomic variables on stock prices and little attention of the responsible parties and the lack of knowledge of this issue in the Sri Lankan context could not be added to the information set available to the above parties. In order to fill this gap in the literature in the emerging Sri Lankan Stock Market, this study will add immensely to the existing literature of emerging Sri Lankan Stock Market. Therefore, the research problem of this study is to find out whether there is any relationship between macroeconomic variables and stock prices in the Colombo Stock Exchange.

\subsection{Objectives of This Study}

The objective of the study is to find out the relationship between different macroeconomic variables and stock price.

\subsection{Hypothesis of This Study}

$\mathrm{H}$ 1: There is a significant relation between inflation and stock prices

$\mathrm{H} 2$ : There is a significant relation between interest rate and stock prices

H 3: There is a significant relation between GDP deflator and stock prices

H4: There is a significant relation between unemployment rate and stock prices

\subsection{Data Collection}

The study covers the periods from 1990 to 2017 and employs time series data. Data relevant to this study collected from such secondary sources as Central Bank Annual Reports 1990 2017 and Economic and Social Statistics in Sri Lanka 1990 - 2017. Correlation and OLS panel Regression techniques have employed for investigating the relationship between the variables under study.

\section{Empirical Study on Marco Economic Factors and Stock Prices}

Khan, Khan I2018) conducted a study on the topic of The Impact of Macroeconomic Variables on Stock Prices: A Case Study of Karachi Stock Exchange. They found that stock prices of Karachi Stock Exchange in long term were significantly affected by money supply, exchange rate, and interest rate. In short term all the variables were insignificant except exchange rate which was negatively co-integrated with stock prices. 


\section{Ml Macrothink}

International Journal of Accounting and Financial Reporting

ISSN 2162-3082

2019, Vol. 9, No. 4

Badullahewage (2017) conducted a study on the topic of The Effects of Macroeconomic Factors on the Performance of Stock Market in Sri Lanka.The results of the analysis revealed that all these factors had an inseparable impact over the performance of the stock market and Sri Lankan stock market performance had eventually over gone through many ups and downs because of them as well. It had been conclude that inflation and exchange rates had comparatively higher effects on the stock market performance.

Jahufer and Iran, M. (2014) studied about Contribution of macroeconomic factors on the stock market performance in Sri Lanka. They found that there was a long run equilibrium relationship between the variables and the results of the VEC model there was a short run relationship between stock market index and money supply.

Keray (2009) carried out a study about inter relationship between stock prices and monitory indicators for Jamaica. He found that stock price index was positively influenced by inflation rate and money supply and exchange rate and interest rate negatively impact on stock price index.

Wickramasinghe (2006) studies about the relationship among stock price and Macro economic variables in Sri Lanka. There was a cointergration relationship among the stock prices and macro-economic variables.

Addy et.al (20140 analyzed the relationship between macro-economic variables and Ghana Stock Exchange. This study revealed that there was a long run relationship between some of the macro economic variables and stock market index.

\subsection{Conceptualization}

After careful study of review of literature, researcher develops the following conceptual model.

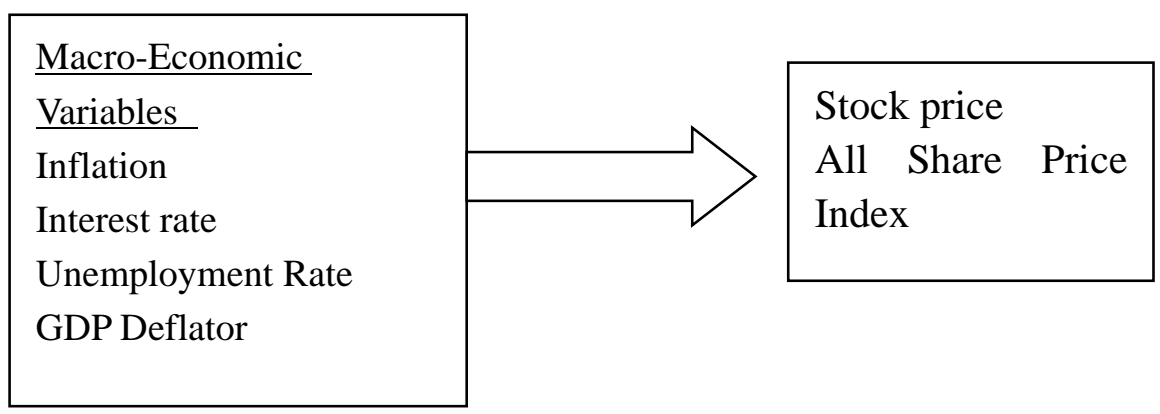

Source: Developed by Researcher

\subsection{Definition of Variables}

Stock price index: Stock price index is a measure reflecting the general fluctuation of stock in the stock market.

Inflation is defined as a sustained increase in the general level of prices for goods and services in a county, and is measured as an annual percentage change. 


\section{Macrothink}

International Journal of Accounting and Financial Reporting

ISSN 2162-3082

2019, Vol. 9, No. 4

Interest rate: The interest rate is the percent of principal charged by the lender for the use of its money

The GDP Deflator: The GDP deflator, also known as the implicit price deflator, measures the impact of inflation on the gross domestic product during a specified period, usually a year.

Unemployment Rate: Percentage of total work force who is unemployed and is looking for a paid job.

\section{Results of This Study}

Figure 1 given below indicates the trend of the variables used in this study for the year from 1990 to 2017.
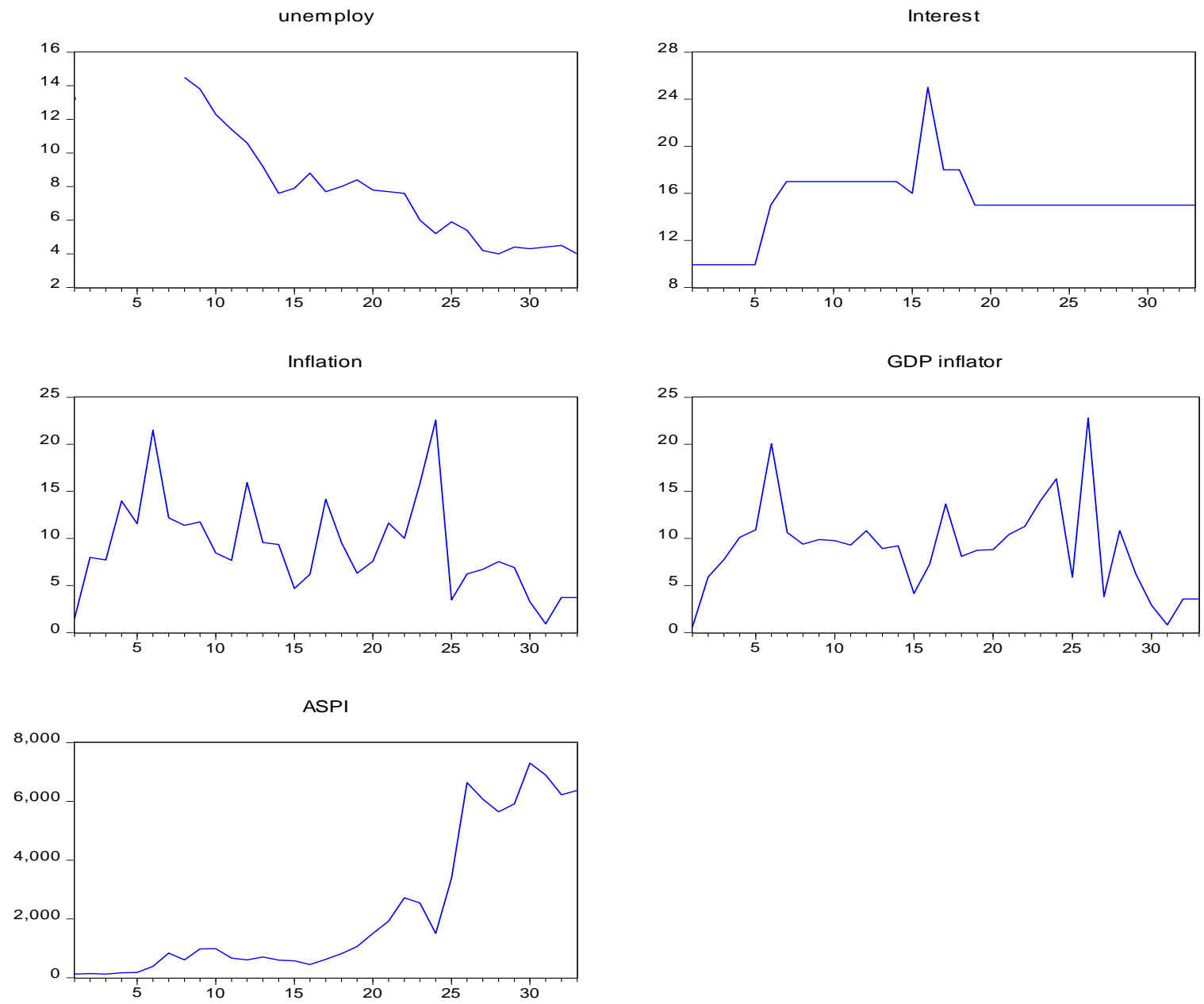

Figure 1. The trend of the variables used in this study

According to the above figure unemployment rate has decreasing trend during the period from 1990 to 2017. All share price index has increasing trend during the research period. Furthermore the interest rate, inflation rate and GDP deflator trend have the fluctuations during the research period. 


\subsection{Descriptive Summary Statistics}

Preliminary analysis of the data was carried out for the years 1990 and 2017. Descriptive statistics are also useful to make general observations about the data collected. They report on the trends and patterns of data and provide the basis for comparisons between variables. General description of these variables appears on the Table 1 as below.

Table 1. Descriptive statistics

$\begin{array}{lccccc} & \text { ASPI } & \text { GDP_deFLA... } & \text { INFLATION } & \text { INTEREST } & \text { UNEMPLOY } \\ \text { Mean } & 2719.072 & 8.561111 & 8.394074 & 15.96037 & 7.733333 \\ \text { Median } & 1503.020 & 8.920000 & 7.580000 & 15.00000 & 7.700000 \\ \text { Maximum } & 7298.950 & 22.80000 & 22.56000 & 25.00000 & 14.50000 \\ \text { Minimum } & 121.9700 & 0.580000 & 0.920000 & 9.930000 & 4.000000 \\ \text { Std. Dev. } & 2545.791 & 4.830809 & 4.865897 & 2.384263 & 3.173932 \\ \text { Skewness } & 0.704782 & 0.723321 & 0.914645 & 1.535298 & 0.652620 \\ \text { Kurtosis } & 1.771905 & 4.203341 & 3.983869 & 9.955951 & 2.426063 \\ & & & & & \\ \text { Jarque-Bera } & 3.931973 & 3.983401 & 4.853584 & 65.04054 & 2.287187 \\ \text { Probability } & 0.140018 & 0.136463 & 0.088320 & 0.000000 & 0.318672 \\ & & & & & \\ \text { Sum } & 73414.95 & 231.1500 & 226.6400 & 430.9300 & 208.8000 \\ \text { Sum Sq. Dev. } & 1.69 \mathrm{E}+08 & 606.7547 & 615.6009 & 147.8025 & 261.9200 \\ \text { Observations } & 27 & 27 & & & 27\end{array}$

The results showed that all share price index had a mean value of 2719.072 with a minimum of 121.97, a maximum of 7298.950, skewness 0.704782 and kurtosis of 1.771905. GDP inflation had a mean value of 8.5611 , minimum of 0.580000 , maximum of 22.800000 skewness of 0.723321 and kurtosis of 4.203341. Comparatively, inflation had a mean value of 8.394074 , minimum of -0.92000 , maximum of 22.56000 , skewness of 0.91465 and kurtosis of 3.983869. Interest rate had a mean value of 15.97037, minimum of 09.93, maximum of 25.0000 skewness of 1.535298 and kurtosis of 9.955951. Skewness measures the degree and direction of asymmetry. A symmetric distribution such as a normal distribution has a skewness of 0 , while nearly normal distributions will have skewness values close to 0 .

\subsection{Multicolonearity Test}

Multi co linearity can be measured using Variance Inflation Factor or Tolerance test. In this study, VIF was used.

Table 2

\begin{tabular}{cccc}
\hline \hline Variable & $\begin{array}{c}\text { Coefficient } \\
\text { Variance }\end{array}$ & $\begin{array}{c}\text { Uncentered } \\
\text { VIF }\end{array}$ & $\begin{array}{c}\text { Centered } \\
\text { VIF }\end{array}$ \\
\hline \hline C & 3878214. & 49.69660 & NA \\
INFLATION & 6619.922 & 7.911259 & 1.934119 \\
INTEREST & 15235.85 & 50.80210 & 1.068759 \\
UNEMPLOY & 8593.188 & 7.653612 & 1.068204 \\
GDP_DEFLATOR & 6492.588 & 7.967456 & 1.869658 \\
\hline \hline
\end{tabular}




\section{1l Macrothink}

International Journal of Accounting and Financial Reporting

ISSN 2162-3082 2019, Vol. 9, No. 4

According to the Table 2 VIF values are below 10 and when VIF values are less than 10 then there is no multi-co-linearity problem.

\subsection{Correlation Analysis}

To find out the relationship among variables correlation analysis was carried out. The summary of the results are presented in the Table 3.

Table 3. Correlation analysis

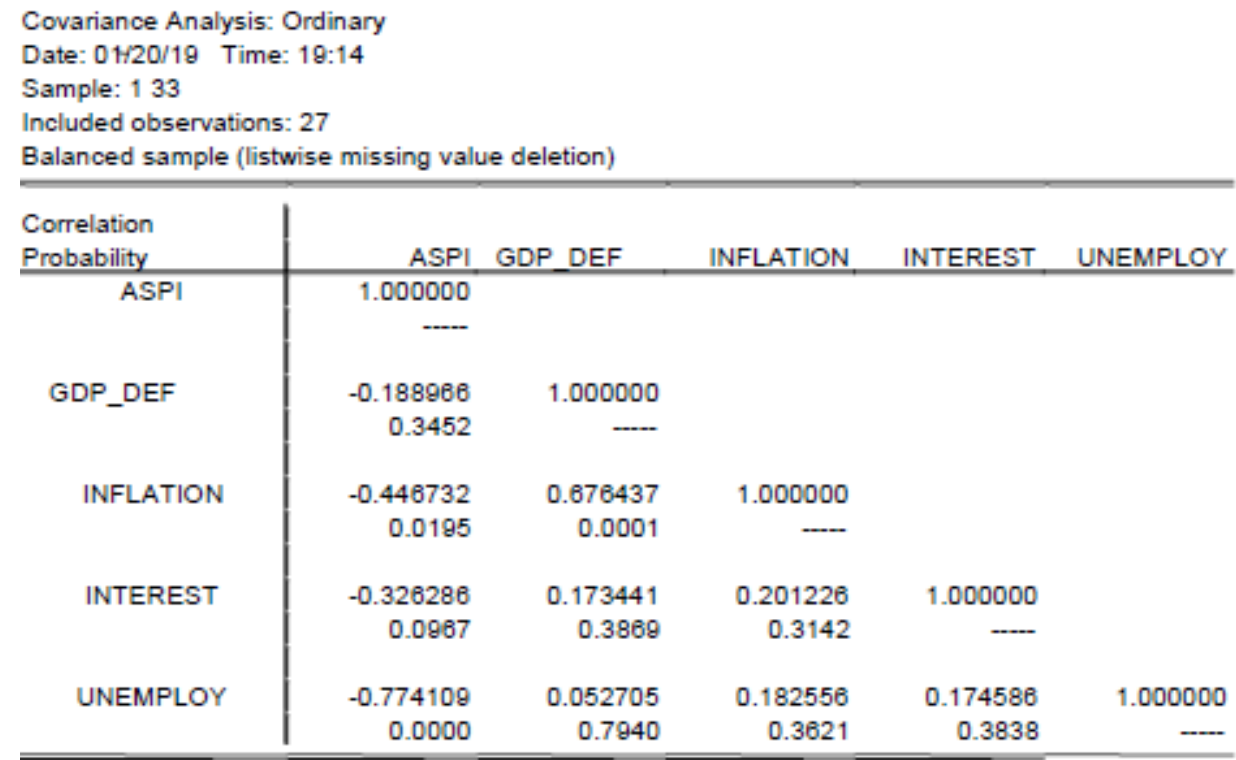

These weak relationships between the explanatory variables are also the indication that there is no severe issue of multi-co-linearity.

\subsection{Regression Models Used in This Study}

To investigate the impact of macroeconomic variables on stock PRICE, the model used for the regressions analysis is expressed in the general form as given in equation 1 .

$$
\mathrm{ASPI}=\mathrm{f}\left(\mathrm{INFLA}, \mathrm{INT}, \mathrm{GDP} \_ \text {deFLA, UNEMPLOY }\right) \quad(\text { Equation 1) }
$$

To investigate the impact macro-economic factors on stock market performance as measured by all share price Index the model used for the regressions analysis is expressed as follows.

$$
\mathrm{ASPI}=\beta_{0}+\beta_{1} \mathrm{INFLA}+\beta_{2} \mathrm{INT}+\beta_{3} \text { GDP_deFLA }+\beta_{4} \mathrm{UNEMPLOY}+\mathrm{E}_{\mathrm{it}}
$$

To find out the impact of macroeconomic variables on stock prices, OLS regression was carried out. Table 4 gives the summary of the Regression Results. 


\section{Macrothink International Journal of Accounting and Financial Reporting Institute ${ }^{\mathrm{TM}}$

Table 4. OLS regression results

\begin{tabular}{lrlrl}
\hline \multicolumn{1}{c}{ Variable } & Coefficient & Std. Error & t-Statistic & Prob. \\
\hline C & 10653.25 & 1969.318 & 5.409616 & 0.0000 \\
INFLATION & -198.1402 & 81.36290 & -2.435265 & 0.0234 \\
INTEREST & -163.3560 & 123.4336 & -1.323432 & 0.0199 \\
GDP_DE & 68.43234 & 80.57660 & 0.849283 & 0.4049 \\
$\quad$ UNEMPLOY & -549.5190 & 92.69945 & -5.927964 & 0.0000 \\
\hline R-squared & 0.724911 & Mean dependent var & 2719.072 \\
Adjusted R-squared & 0.674895 & S.D. dependent var & 2545.791 \\
S.E. of regression & 1451.558 & Akaike info criterion & 17.56424 \\
Sum squared resid & 46354459 & Schwarz criterion & 17.80421 \\
Log likelihood & -232.1172 & Hannan-Quinn criter. & 17.63559 \\
F-statistic & 14.49356 & Durbin-Watson stat & 1.523894 \\
Prob(F-statistic) & 0.000006 & & & \\
\hline
\end{tabular}

The above Table shows the estimated result of model $1 . \mathrm{R}$ square shows that the model explained $72.4911 \%$ of total variations of the dependent variable. It means that $72.4911 \%$ of the changes in dependent variable are described by independent variables taken in this study.

As observed, the results show that inflation has a coefficient of -198.1402 with t statistics of 5.409616 with a $\mathrm{p}$ value of 0.0234 Thus, from the results, it can be stated that there is a significant relation between inflation and stock prices measured by all share price index. $\mathrm{H}_{1}$ is supported.

Interest rate has a coefficient of -163.3560 with $t$ statistics of -1.323432 with a $p$ value of 0.01993. It can be stated that there is a significant relation between interest rate and stock prices measured by all share price index. $\mathrm{H}_{2}$ is supported. Similarly, the co-efficient value of GDP inflator is 68.43234 and it has a t value 0.849283 with a $\mathrm{p}$ value $0.4049 . \mathrm{H}_{3}$ is not supported. The coefficient value of the unemployment is -549.5190 and it has a t value of -5.927964 with a $\mathrm{p}$ value of 0.0000 . There is a significant relation between unemployment rate and stock prices measured by all share price index. $\mathrm{H}_{4}$ is supported. Durbin Watson test is a test used to defect auto correlation. From the Table 03 Durbin Watson stat value is 1.523894. This value less than 3 indicating that there is no auto correlation issues.

\subsection{Residuals Normality Test}

To test the validity of the Model residual normality test was carried out. Figure 2 shows the histogram of the residuals of model 1. Since the probability of Jarque-bera statistics is greater than $5 \%(0.575972)$ and therefore, the $\mathrm{H}_{0}$ of residuals are normally distributed can be accepted. The kurtosis of the histogram is less than 3 and its left tail is heavy and also skewness is closer to $0 .(0.020535)$ 


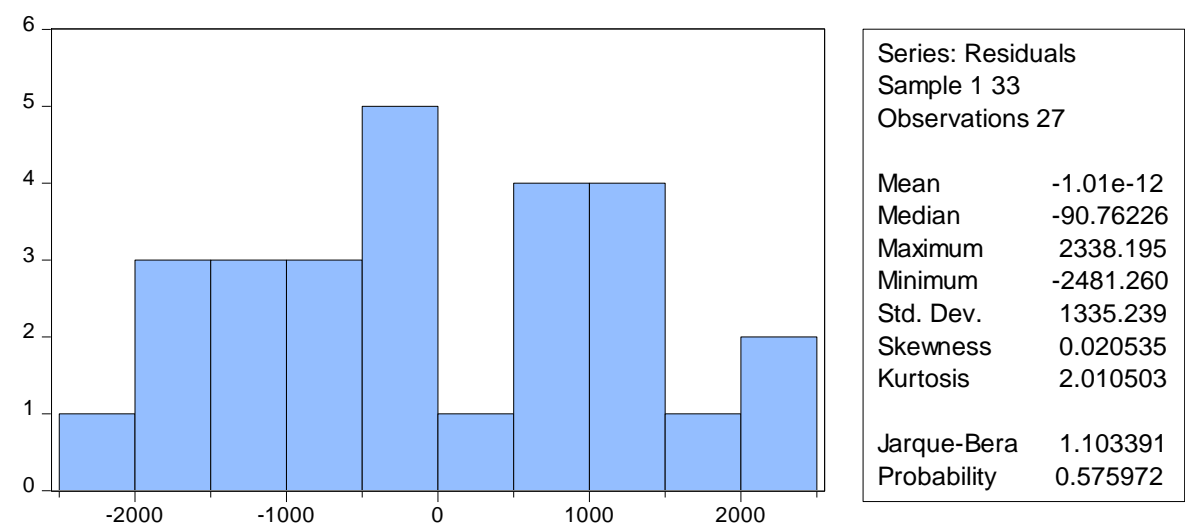

Figure 2. Residuals normality test

\section{Findings of this Study}

This study investigated the relationship between macro-economic variables on stock prices in Sri Lanka. The results show that there is a significant negative relationship among inflation rate, interest rate and Unemployment rate with stock prices. The negative coefficient of inflation rate suggests that with increase in inflation rates by $1 \%$ will fall stock prices by $-198.142 \%$. Whereas the negative coefficient of interest rate suggests that with increase in interest rates by $1 \%$ will fall stock prices by $-163.3560 \%$. Furthermore the negative coefficient of unemployment rate suggests that with increase in unemployment rates by $1 \%$ will fall stock prices by --549.519\%. The similar results have also been found in study done by Badullahewage (2017) and Menike (2006). By taking into consideration the above factors, the results of a study of this nature will be of enormous importance for both local and foreign investors, stock market regulators, multinational .This study will help to the stock market analysts and policy makers. Therefore, this type of study is very essential to promote the stock market. This study also used residual normality test to check the validity of the model.

\subsection{Contribution of This Study}

The stock exchange acts as the most important market for capital and a well-developed capital market is essential to promote economic development. The Sri Lankan government has been offering a number of incentives to boost the stock market. Specially, foreign investors are granted substantial incentives to invest in Sri Lankan company shares.

The government has taken several significant steps to boost the Sri Lankan Stock Market. Further, the capital market plays an important part in the economy and companies listed in the CSE are already involved in the development of infrastructure - the Power Sector, Telecom, Water and Health while other sectors in the CSE cover a significant role in the Sri Lankan macroeconomic.

\section{References}

Abu-Libdeh, H., \& Harasheh, M. (2011). Testing for correlation and causality relationships between stock prices and macroeconomic variables: The case of Palestine securities exchange. International Review of Business Research Papers, 7(5), 141-154. 


\section{Macrothink}

International Journal of Accounting and Financial Reporting

ISSN 2162-3082

2019, Vol. 9, No. 4

Adam, A., \& Tweneboah, G. (2008). Macroeconomic factors and stock market movement: Evidence from Ghana. http://dx.doi.org/10.2139/ssrn.1289842

Addy, F. K., Sampson, V., \& Yakubu, A. S. (2004). Relationship between stock market performance and macro-economic variables in Ghana. Issues in Business Management and Economics, 2(3), 46-53.

Badullahewage, S. U. (2017). The Effects of Macroeconomic Factors on the Performance of Stock Market in Sri Lanka. International Journal of Innovation and Economic Development, 3(6), 33-41.

Bhunia, A. (2012). A causal relationship between stock indices and exchange rates-empirical evidence from India. Research Journal of Finance and Accounting, 3(1), 47-54.

Bilson, C., Brailsford, T., \& Hooper, V. (2001). Selecting macroeconomic variables as explanatory factors of emerging stock market returns. Pacific-Basin Finance Journal, 9(4), 401-426. http://dx.doi.org/10.2139/ssrn.201908

Jahufer, A., \& Iran, M. (2014). Contribution of macroeconomic factors on the stock market performance in Sri Lanka. Journal of Management, $X(1)$.

Keray, R. (2009). Is there a long run relationship between stock prices and monetory variables? Evidence from Jamaica. Financial Stability department, Bank of Jamaicu.

Khan, J., \& Khan, I. (2018). The Impact of Macroeconomic Variables on Stock Prices: A Case Study of Karachi Stock Exchange. Bus. Eco. J., 9, 365. http://dx.doi.org/10.4172/2151-6219.1000365Page 2 of

Menake, L. M. C. S. (2006). The Effect of Macroeconomic Variables on Stock Prices in Emerging Sri Lankan Stock Market. Sabaragamuwa University Journal, 6(1), 50-67.

Wickremasinghe, G. B. (2006). Marco Economic factors and stock prices: some empirical evidence from Sri Lanka. Victoria University.

\section{Copyright Disclaimer}

Copyright for this article is retained by the author(s), with first publication rights granted to the journal.

This is an open-access article distributed under the terms and conditions of the Creative Commons Attribution license (http://creativecommons.org/licenses/by/4.0/) 